\title{
Impact of Storage Temperature on Physiological Changes and Shelf Life of Mango CV. Mahachanok
}

\author{
Napong Kantanet ${ }^{1}$, Pavalee Chompoorat ${ }^{1 *}$ \\ ${ }^{1}$ Faculty of Engineering and Agro-Industry, Maejo University, Chiang Mai 50290, Thailand \\ *Corresponding author. Email: pavalee@mju.ac.th
}

\begin{abstract}
Mango (Mangifera indica L.) is one of the most popular fruits in Thailand. It is rich in dietary fiber, vitamin C, provitamin A, carotenoids and other phytochemical compounds. Mango is characterized by climacteric fruit and ripen rapidly after harvest. Commercial growers normally harvest mango during its horticultural maturity in order to maintain its quality. The most important environmental factor that influences the deterioration of fruits is temperature. Mango as a tropical fruit can respond unfavourably to storage at low temperature. Thus, the objective of this study is to investigate an effect of storage conditions on physical, physiological, chemical qualities and shelf-life of mango cv. Mahachanok. The mangoes were kept in cold storage at $5^{\circ} \mathrm{C}$ with chitosan, $5^{\circ} \mathrm{C}, 8^{\circ} \mathrm{C}, 10^{\circ} \mathrm{C}$ and $13^{\circ} \mathrm{C}$ with $95 \% \mathrm{RH}$ in a plastic basket covered with paper. External appearance, chilling injury, weight loss, skin and pulp color, total soluble solids, titratable acidity, texture and sensory characteristics were determined every 7 days during storage. The results revealed that mango stored at $8^{\circ} \mathrm{C}$ can prolong the shelf-life up to 35 days. Using a storage room at $8^{\circ} \mathrm{C}$, it can retard water loss, the drop in sensory properties, texture and other chemical characteristics. Using only storage temperature at $5^{\circ} \mathrm{C}$ without chitosan coating was sufficient to prolong the storage life of mango. It appeared that mango qualities reduced after being stored at $14^{\text {th }}$ and $21^{\text {st }}$ day of storage in 10 and $13^{\circ} \mathrm{C}$, respectively.
\end{abstract}

Keywords: Mango, Postharvest handling, Temperature, Shelf life.

\section{INTRODUCTION}

Mango (Mangifera indica L.) belongs to the dicotyledonous clan of Anacardiaceae and the fruit is known as "king of fruits" [1]. It provides an excellent flavor, attractive odor, and delicious taste [2]. Mango is a tropical fruit that is important for the economy of Thailand. There are more than 100 cultivated varieties. It can grow in almost the whole country. Therefore, mango is a fruit plant that is popularly grown and consumed as a number one of all fruits in Thailand [3]. Thailand has an important portion of its revenue from exports of agricultural products and mango is one of the country's most important exports, which can be seen from the amount of mangoes exported in 2018 which are worth approximately 50 million USD[4]. Mango is a climacteric fruit with relatively high respiration, and short postharvest life. That is a limiting factor in a longdistance marketing of the fruit [5]. The fruit is rich in varieties of phytochemicals and nutrients. A $100 \mathrm{~g}$ of mango contained water $83.46 \mathrm{~g}$, energy $60 \mathrm{kcal}$, protein $0.82 \mathrm{~g}$, total lipid (fat) $0.38 \mathrm{~g}$, carbohydrate $14.98 \mathrm{~g}$, total dietary fiber $1.6 \mathrm{~g}$, total sugar $13.66 \mathrm{~g}$, Calcium (Ca) 11 $\mathrm{mg}$, Ferrum (Fe) $0.16 \mathrm{mg}$, Magnesium (Mg) $10 \mathrm{mg}$, Phosphorus (P) $14 \mathrm{mg}$, Potassium (K) $168 \mathrm{mg}$, Sodium (Na) $1 \mathrm{mg}$, Zinc (Zn) $0.09 \mathrm{mg}$, vitamin C $36.4 \mathrm{mg}$, thiamin $0.028 \mathrm{mg}$, riboflavin $0.038 \mathrm{mg}$, niacin $0.669 \mathrm{mg}$, vitamin B6 $0.119 \mathrm{mg}$, folate $43 \mathrm{mg}$, vitamin A $54 \mathrm{mg}$, vitamin A 1082 IU, vitamin E $0.90 \mathrm{mg}$, vitamin K $4.2 \mathrm{mg}$, saturated fatty acids $0.092 \mathrm{~g}$, total monounsaturated fatty acids $0.140 \mathrm{~g}$, and total polyunsaturated fatty acids $0.071 \mathrm{~g}$ [6]

Chitosan is a well-known natural alkaline cationic polymer composed of a complex double helix structure and widely exists in the cell walls of lower arthropods such as shrimp, crabs and crustaceans and lower plants such as algae and fungi [7]. Moreover, chitosan has antibacterial properties due to the presence of abundant amino groups on the surface and its special membrane 
structure helps strengthen the abiotic stress resistance and antioxidant aging resistance of fruits and vegetables [8].

Low temperature during fruit storage helps in delaying spoilage, microbial growth and metabolic variations. Thus, low temperature could maintain fruit qualities and prolongs storage period. However, some products are prone to chilling injury and deteriorate rapidly if stored at below chilling temperatures [9]. Temperature management is a critical factor affecting the postharvest shelf life of mango. Mangoes are often held at 8 to $13{ }^{\circ} \mathrm{C}$. In addition, relative humidity about 90 to $95 \%$ should be maintained during postharvest handling of mango to attenuate water loss. Fruit quality plays a serious role in determining consumer acceptance of the fruit at the international markets [10]. Therefore, qualities of mango must be controlled to maintain fruit quality during the export. Decay and quality deterioration are postharvest problems of mango fruit during the export.

However, mangoes can be harvested for one season of the year which produces during April to May. Hence, they are released at the same time causing the oversupply problem. Thus, the objective of this work was to determine the effect of storage conditions on physical, physiological, chemical qualities and shelf-life of mango cv. Mahachanok.

\section{MATERIALS AND METHOD}

\subsection{Raw Materials}

Mango CV. Mahachanok in this work was received from an orchard in Chiang Mai, Thailand. After harvesting, the mangoes were transported within two hours to the postharvest laboratory, Maejo University in Chiang Mai. The fruits were sorted by specific gravity method using water. The mangoes were dropped in a bucket of water. The floated mangoes showed a lack of development which were discarded. The selected mangoes were tested with a specific method with $100 \%$ peel green color were selected for this experiment. The fruit with an absence of visible symptoms of disease and mechanical injury were selected for the experiments.

\subsection{Storage Procedure}

The mangos were divided into five treatments with five replicates of each. All of the stored fruits were packed in plastic boxes with size $(37 \mathrm{~cm} \mathrm{X} 55.5 \mathrm{~cm} \mathrm{X}$ $30.5 \mathrm{~cm}$ ) according to the treatments. The treatments were 1) mangoes coated with $2 \%$ chitosan stored continuously at $5^{\circ} \mathrm{C}, 90-95 \% \mathrm{RH}$, (2) mangoes stored continuously at $5^{\circ} \mathrm{C}, 90-95 \% \mathrm{RH}$, (3) mangoes stored continuously at $8{ }^{\circ} \mathrm{C}, 90-95 \% \mathrm{RH}$, (4) mangoes stored continuously at $10^{\circ} \mathrm{C}, 90-95 \% \mathrm{RH},(5)$ mangoes stored continuously at $13^{\circ} \mathrm{C}, 90-95 \% \mathrm{RH}$ until the end of storage. The qualities of the stored fruit was assessed at $0,7,14,21,28$ and 35 days of storage.

\subsection{Weight Loss}

Fruits in each treatment were separately marked before storage and weighed at the start of the experiment for measuring weight loss during storage. The same fruits were consistently weighed at each sampling interval during the whole storage period. The result was expressed on a percentage basis.

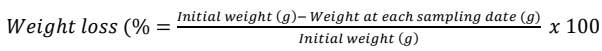

\subsection{Chilling Injury Index}

When chilling injury (CI) symptoms visible as sunken lesions were observed, the fruit were considered to have CI manifestation. The CI index was based on the percentage of total surface area affected by sunken lesions. $5=$ no abnormality $(0 \%), 4=$ trace symptoms $(1-$ $10 \%), 3=$ moderate symptoms, blotchy appearance $(11-$ $25 \%), 2=$ moderate to severe symptoms $(26-50 \%)$ and 1 $=$ severe symptoms $(>50 \%)$.

\subsection{Skin \& Pulp Color}

Color was measured with a Minolta colorimeter (Minolta Co. Ltd., Osaka, Japan) on the basis of the CIELAB color system ( $\mathrm{L}^{*}, \mathrm{a}^{*}$ and $\mathrm{b}^{*}$ ). In this system $\mathrm{L}^{*}$, $a^{*}$ and $b^{*}$ describe a three dimensional space, where $L^{*}$ is the vertical axis and its value varies from 100, for perfect white, to zero, for black. Values of $a^{*}$ and $b^{*}$ specify the green-red and blue-yellow axis, respectively, ranging from -60 to +60 or from $-\mathrm{a}$ (green) to $+\mathrm{a}$ (red) and from $-b$ (blue) to $+b$ (yellow). Skin and pulp color was measured at the central part of the fruit with one position per replicate.

\subsection{Total soluble solids (TSS)}

TSS is an index of soluble solids concentration in fruit. A few drops of fruit juice were used for determination of the TSS content by using a digital refractometer (PAL-1, Atago, Japan) Scale range 0- 45 degrees Brix and reported as total soluble solids (\%).

\subsection{Titratable Acidity}

Titratable acidity is measured with a $\mathrm{pH}$ meter. Pipette mango juice $5 \mathrm{ml}$ and distilled water $45 \mathrm{ml}$ in a beaker. It was then filtered immediately with $0.1 \mathrm{~N}$ $\mathrm{NaOH}$ solutions from a burette until the solution has a $\mathrm{pH}$ of 8.2. Titratable acidity was calculated as a percentage of citric acid per $100 \mathrm{ml}$ of mango juice. 


\subsection{Texture Profile Analysis (TPA)}

The mangoes were assessed by using a TA-XT2 texture analyser (Stable Microsystems, Surrey, UK). The texture characteristics of mangoes were analyzed by texture profile analysis (TPA) method. The force required to penetrate $6 \mathrm{~mm}$ inside the fruit using a cylindrical probe diameter of $12.7 \mathrm{~mm}(\mathrm{P} / 0.5)$. The machine was set with compression mode at the speed of $1 \mathrm{~mm} / \mathrm{sec}$. The fruit was pressed into the center and the result was expressed in terms of force recorded in Newton $(\mathrm{N})$.

\subsection{Sensory Properties}

The sensory evaluation of fruit was made after ripening at 21, 28 and 35 days of storage by using a nine point hedonic scale of color, taste, odor, texture and overall acceptability of mango. The samples were evaluated following $(9=$ like extremely, $8=$ like very much, 7 = like moderately, $6=$ like slightly, $5=$ neither like nor dislike, $4=$ dislike slightly, $3=$ dislike moderately, $2=$ dislike very much, $1=$ dislike extremely) by panel of trained Judges.

\subsection{Statistical Analysis}

The data on mango qualities during storage were statistically analysed and subjected to analysis of variance (ANOVA) using completely randomized design with five replicates using SPSS version 20. Significance between means was measured using Duncan's test at 5\% confidence level $(p<0.05)$. Pearson's correlation coefficients were calculated to show relationships between mango properties during storage at 21, 28 and 35 days of storage. A multiple linear regression analysis was also tested to find an association of multiple independent variables (response variables) which were external appearance, weight loss and skin color on the dependent variables (explanatory variables) which were chilling injury index, TSS, hardness and overall characteristics from sensory test.

\section{RESULTS AND DISCUSSION}

\subsection{External Appearance}

Early of storage, it was found that the appearance of each mango were quite high quality, scoring 5 (Fig. 1).

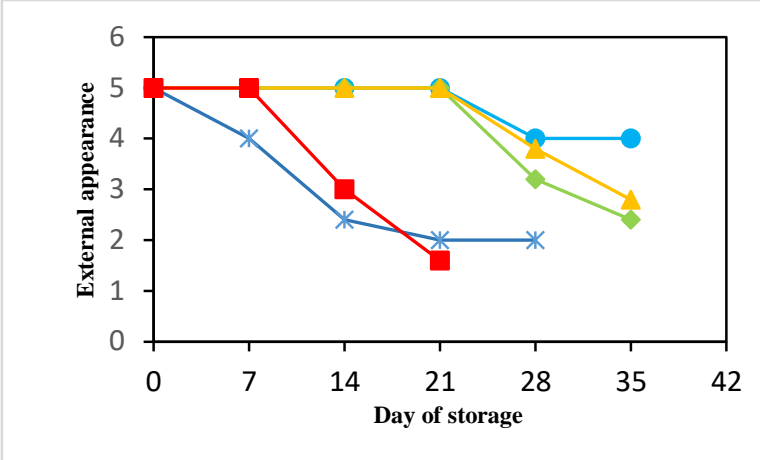

$\longrightarrow 5^{\circ} \mathrm{C}+$ Chitosan $\longrightarrow 5^{\circ} \mathrm{C} \longrightarrow 8^{\circ} \mathrm{C} \longrightarrow 10^{\circ} \mathrm{C} \longrightarrow 13^{\circ} \mathrm{C}$

Figure 1 External appearance of 'Mahachanok' mango fruit stored at $5^{\circ} \mathrm{C}+$ chitosan, $5,8,10$ and $13{ }^{\circ} \mathrm{C}$ until the end of storage.

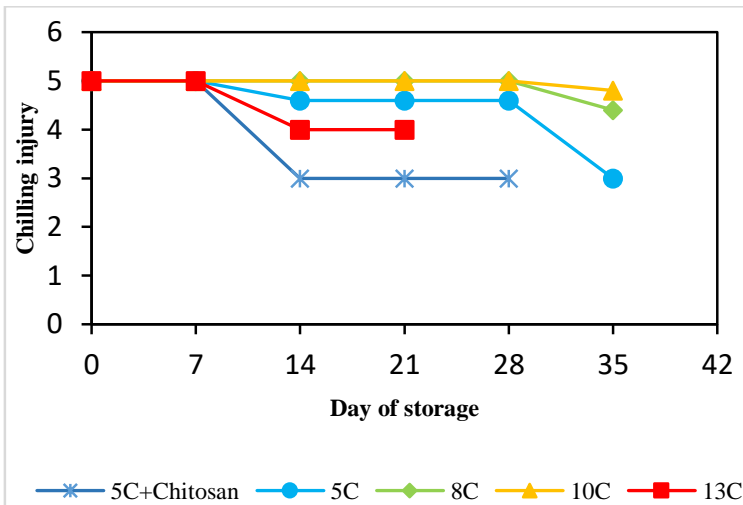

Figure 2 Chilling injury of 'Mahachanok' mango fruit stored at $5^{\circ} \mathrm{C}+$ chitosan, $5,8,10$ and $13{ }^{\circ} \mathrm{C}$ until the end of storage.

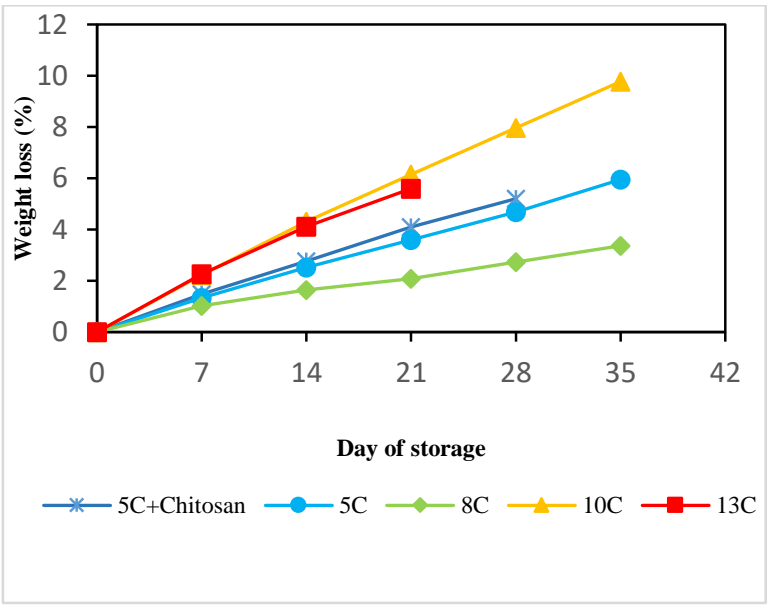

Figure 3 Weight loss (\%) of 'Mahachanok' mango fruit stored at $5^{\circ} \mathrm{C}+$ chitosan, $5,8,10$ and $13^{\circ} \mathrm{C}$ until the end of storage.

Except for mangoes stored at $5^{\circ} \mathrm{C}+$ chitosan. There was an increase in dark and bruise skin. Mangoes stored at 13 ${ }^{\circ} \mathrm{C}$ began to develop anthracnose disease on the peel and $5^{\circ} \mathrm{C}+$ chitosan showed more bruises at 14 day of storage. 
Mango stored at $8^{\circ} \mathrm{C}$ began to develop anthracnose on the peel at 28 days of storage and $10^{\circ} \mathrm{C}$ had searing at the pedicel. At last of storage on day $35^{\text {th }}$, mango stored at $8^{\circ} \mathrm{C}$ and $10^{\circ} \mathrm{C}$ had anthracnose and searing the poles with wilt symptoms occurred throughout the fruit area. Thus, using $8^{\circ} \mathrm{C}$ and $10^{\circ} \mathrm{C}$ for storage temperature could prolong mango shelf-life up to 28 days.

\subsection{Chilling Injury}

The first symptom of chilling injury was the presence of small brown spots on the skin. Then, a considerable part of the skin became dark brown. On the 14 day of storage, the symptoms in mangoes stored at $5^{\circ} \mathrm{C}$ with chitosan and $5^{\circ} \mathrm{C}$ developed chilling injury more rapidly. They appeared to be more dramatic than those stored at 8,10 and $13^{\circ} \mathrm{C}$. At the end of storage on day 35 , samples at $8^{\circ} \mathrm{C}$ and $10^{\circ} \mathrm{C}$ showed the lowest chilling injury symptom.

\subsection{Weight Loss}

The storage periods and temperature significantly affected the weight loss of mango $(p<0.05)$. It displayed an increasing trend with the storage time. The best result in controlling weight loss was obtained in mango stored at 5 and $8{ }^{\circ} \mathrm{C}$ for 3.4 and $5.9 \%$, respectively, while mangoes at $10{ }^{\circ} \mathrm{C}$ on day 35 showed an increase in weight loss up to $9.8 \%$.

\subsection{Skin Color}

The interaction between storage time and temperature not significantly influenced the $\mathrm{L}^{*}$ value of mango $(p>$ $0.05)$. Storing at $5^{\circ} \mathrm{C}+$ chitosan, $5^{\circ} \mathrm{C}, 8^{\circ} \mathrm{C}, 10^{\circ} \mathrm{C}$ and $13^{\circ} \mathrm{C}$ on the last day of storage, mango peels had $\mathrm{L}^{*}$ values of $64.6,63.7,69.3,68.2$, and 70.8, respectively. Storage at 5,8 and $10^{\circ} \mathrm{C}$ did not significantly affect a* $(p<0.05)$, on the last day of storage. The skin color of the mangoes had affected by chitosan coating starting on day 7 , as observed by the increase in $\mathrm{a}^{*}$ values throughout the storage period (Fig. 4).
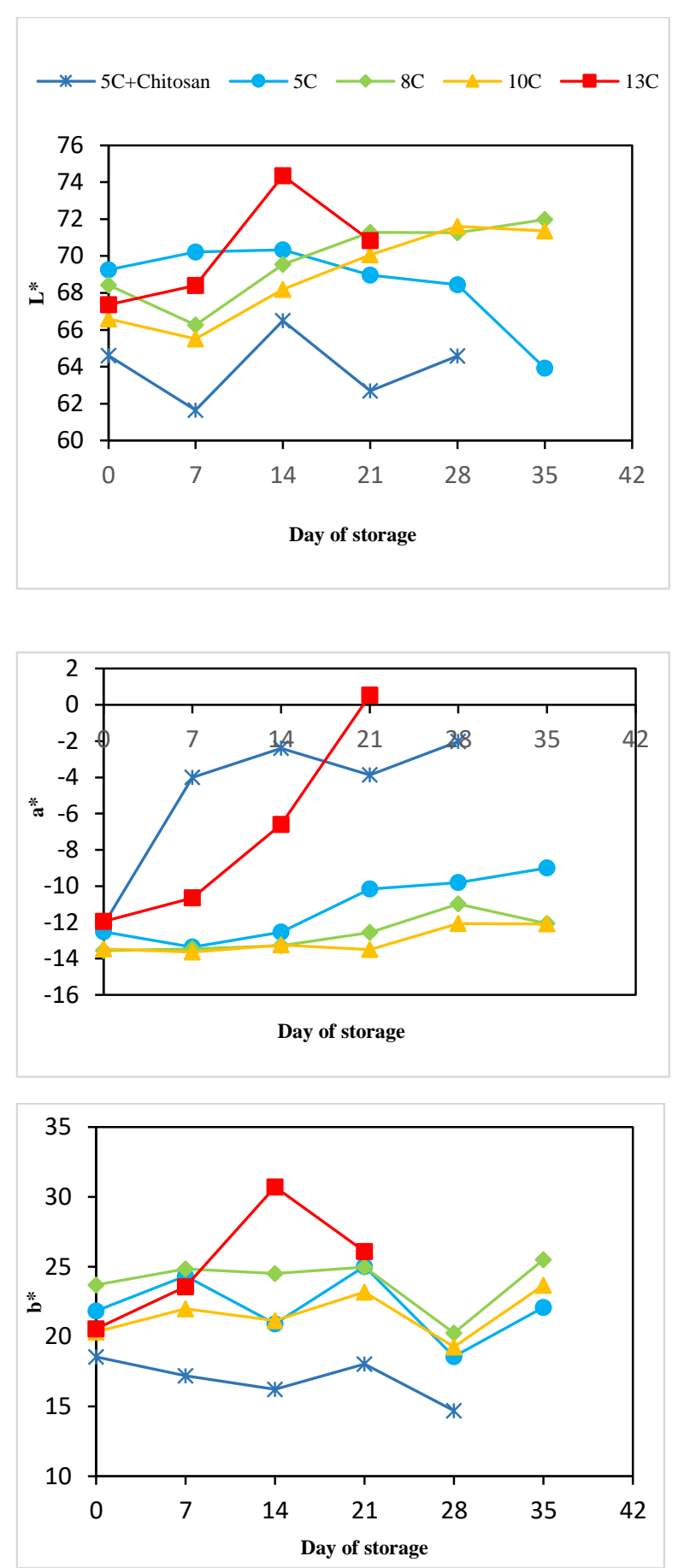

Figure 4 Skin color of 'Mahachanok' mango fruit stored at $5^{\circ} \mathrm{C}+$ chitosan, $5,8,10$ and $13^{\circ} \mathrm{C}$ until the end of storage.

An increase in $\mathrm{a}^{*}$ indicates a decrease in the green color of the mango peel. Storage at 5,8 and $10^{\circ} \mathrm{C}$ did not significantly affect $\mathrm{b}^{*}$ value on the last day of storage ( $p<$ $0.05)$. Mango skin was brighter with the same yellowish after using storage temperature at 8 and $10^{\circ} \mathrm{C}$ on day 35 .

\subsection{Pulp Color}

At 14 days of storage, the $\mathrm{L}^{*}, \mathrm{a}^{*}$ and $\mathrm{b}^{*}$ values began to differ significantly. The last day of storage, the fruits 
were stored at $5{ }^{\circ} \mathrm{C}, 8^{\circ} \mathrm{C}$ and $10^{\circ} \mathrm{C}$ had no significant differences in $\mathrm{L}^{*}, \mathrm{a}^{*}$ and $\mathrm{b}^{*}$ value changes (Fig. 5).
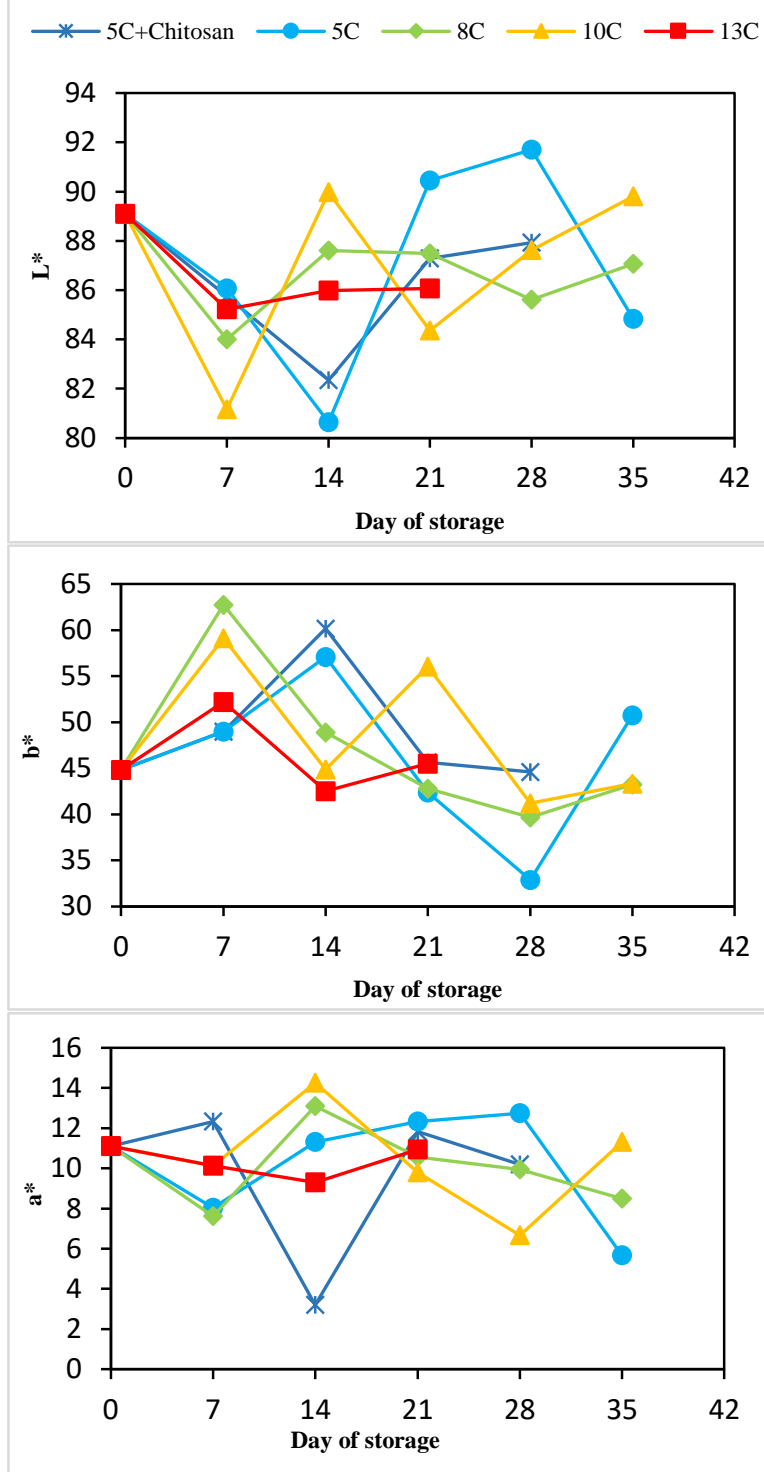

Figure 5 Pulp color of 'Mahachanok' mango fruit stored at $5^{\circ} \mathrm{C}+$ chitosan, $5,8,10$ and $13{ }^{\circ} \mathrm{C}$ until the end of storage.

\subsection{Total Soluble Solids}

The result indicated that total soluble solid (TSS) content has changed over the course of storage significantly (Fig. 6).

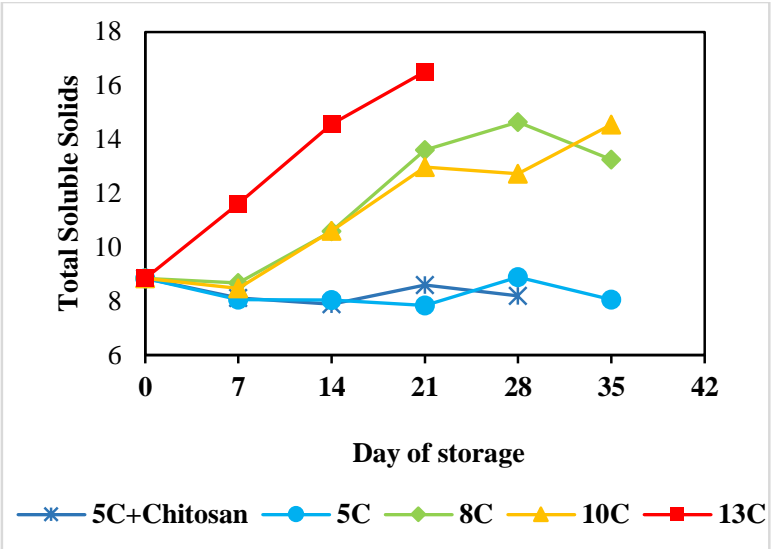

Figure 6 Total Soluble Solids of 'Mahachanok' mango fruit stored at $5^{\circ} \mathrm{C}+$ chitosan, $5,8,10$ and $13{ }^{\circ} \mathrm{C}$ until the end of storage.

When the shelf life was longer, it showed an increase in TSS in the end of storage at 8,10 and $13^{\circ} \mathrm{C}$ for $13.3 \%, 14.6 \%$ and $16.5 \%$ respectively. However, storing at $5^{\circ} \mathrm{C}+$ Chitosan and $5^{\circ} \mathrm{C}$ had little changes. Higher temperature during storage resulted in a higher TSS content than low storage temperatures.

\subsection{Titratable Acidity}

Changes in the titrated acidity (TA) of mangoes kept at different temperatures shown in Figure 7.

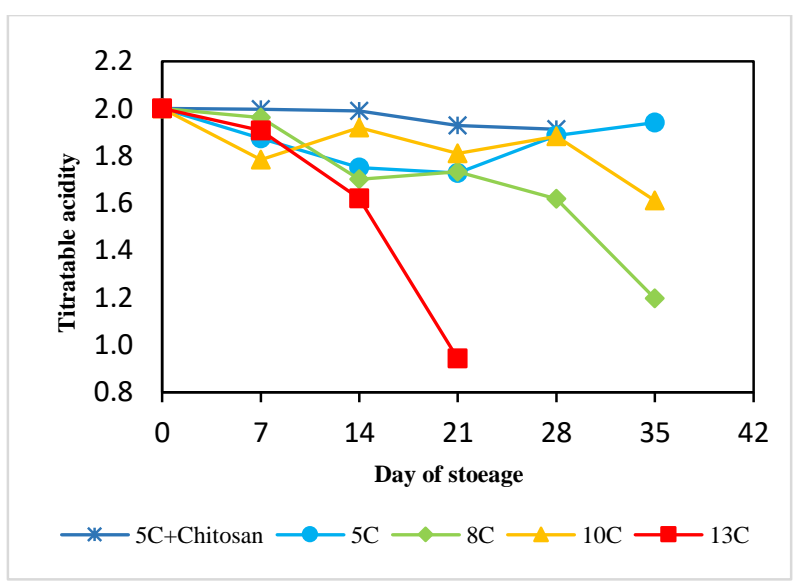

Figure 7 Titratable acidity of 'Mahachanok' mango fruit stored at $5^{\circ} \mathrm{C}+$ chitosan, $5,8,10$ and $13{ }^{\circ} \mathrm{C}$ until the end of storage.

The results revealed that the TA decreased throughout all treatments. Using $5^{\circ} \mathrm{C}+$ chitosan and $5^{\circ} \mathrm{C}$ for storage, it affected the change of TA with $1.9 \%$ on the last day. Mangoes stored at $8^{\circ} \mathrm{C}, 10^{\circ} \mathrm{C}$ and $13^{\circ} \mathrm{C}$ showed a significant decrease in TA during storage at 1.3, 1.5 and 0.9 , respectively, on the last day of storage. In a study of bulk storage, mango pulp also lost vitamin $\mathrm{C}$ during storage [11]. 


\subsection{Texture Properties}

Hardness is the force that is most valuable during the first compression and described as hardness, softness, tenacity, and strength of mangoes. The result indicated mango hardness significantly decreased over the course of storage (Fig. 8).
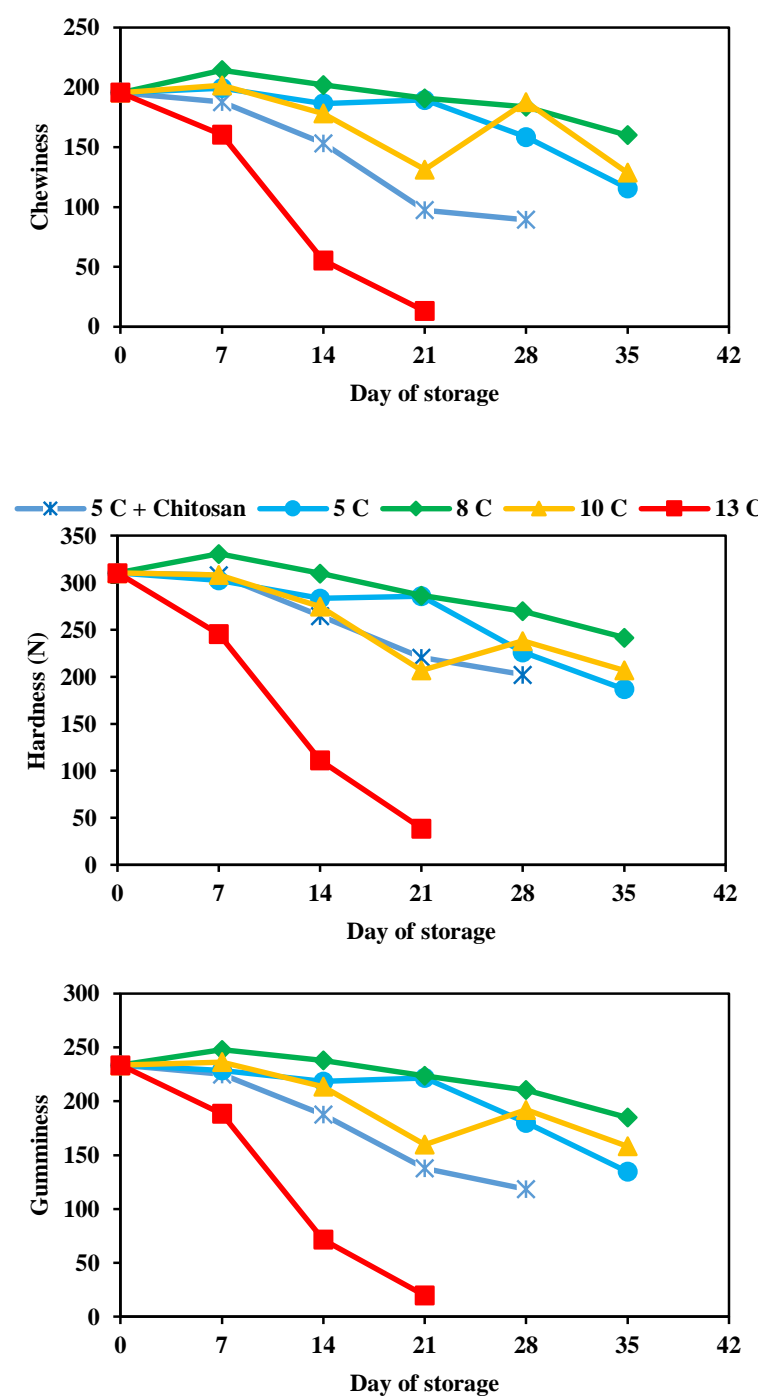

Figure 8 Hardness, Gumminess and Chewiness of 'Mahachanok' mango fruit stored at $5^{\circ} \mathrm{C}+$ chitosan, 5,8 , 10 and $13{ }^{\circ} \mathrm{C}$ until the end of storage.

Mangoes stored at $8^{\circ} \mathrm{C}$ can retain the most Hardness during storage. At the end of storage on day 35 at $5^{\circ} \mathrm{C}$, $8^{\circ} \mathrm{C}$ and $10^{\circ} \mathrm{C}$, the hardness of the mangoes were 186.9 , 241.6 and $206.9 \mathrm{~N}$, respectively.

The gumminess significantly decreased over the course of storage. The storage temperature at $8^{\circ} \mathrm{C}$ was an optimum for mangoes as it causes the least change in gumminess. At the end of storage on day 35 at $5^{\circ} \mathrm{C}, 8^{\circ} \mathrm{C}$ and $10^{\circ} \mathrm{C}$, the gumminess of the mangoes were 134.6, 184.9 and 158.3 , respectively.
The result of chewiness of mango during storage depicted the same trend as hardness and gumminess. At the end of storage on day 35 at $5^{\circ} \mathrm{C}, 8^{\circ} \mathrm{C}$ and $10^{\circ} \mathrm{C}$, the Chewiness of the mangoes were 115.7, 159.9 and 128.7 respectively.

\subsection{Sensory characteristics}

A sensory analysis determined the quality of the mangoes in terms of flavor, color, odor, texture and overall characteristics. The result indicated that sensory characteristics of mangoes decreased significantly over the course of storage (Fig. 9).
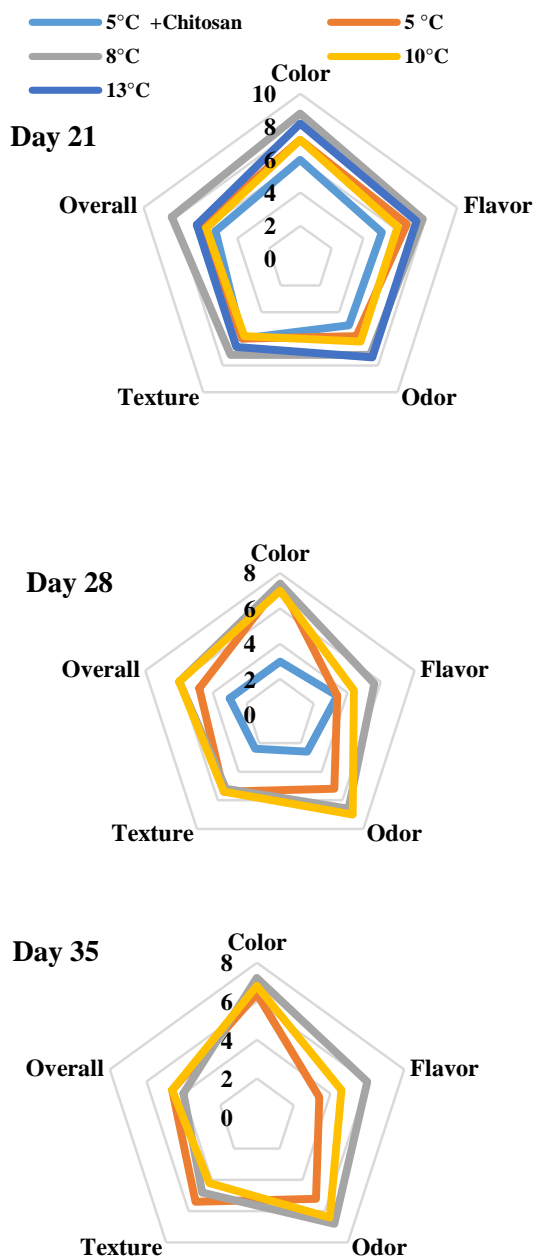

Figure 9 Sensory characteristics of 'Mahachanok' mango fruit stored at $5^{\circ} \mathrm{C}+$ chitosan, $5,8,10$ and $13{ }^{\circ} \mathrm{C}$ until the end of storage.

On the basis of flavor, statistical analysis of the hedonic test showed that a storage temperature used at $8^{\circ} \mathrm{C}$ treatment obtained the highest score of 7.8 points at 21 day of storage. On the $28^{\text {th }}$ of storage day, mangoes stored at $8^{\circ} \mathrm{C}$ had the highest score of 5.6 points. The last day of storage, mangoes stored at $8^{\circ} \mathrm{C}$ had the highest flavor score of 6.0 points, which was higher than other 
treatments. The same trend was revealed with color, odor, texture and overall characteristics. At the end of storage, mangoes stored at $8^{\circ} \mathrm{C}$ had the highest sensory acceptance of color, taste, smell than the other treatments.

\subsection{Pearson Correlation and Multiple Regression Model}

The relationship among pairs of parameters from physical properties (chilling injury index, external appearance and weight loss), chemical properties (TSS and TA), color of skin and pulp and sensory properties of mango across treatments were shown in Table 1.

Table 1 Pearson correlations between each pair of variables of Chilling jury, External appearance, Weight loss, Skin color, Pulp color, Total Soluble Solids, Titratable acidity, Hardness, Gumminess, Chewiness, Color, Flavor, Odor, Texture and Overall parameters.

\begin{tabular}{|c|c|c|c|c|c|c|c|c|c|c|c|c|c|c|c|c|c|c|}
\hline \multirow[b]{2}{*}{ Variables } & \multicolumn{3}{|c|}{ Physical properties } & \multicolumn{2}{|c|}{ Chemical properties } & \multicolumn{6}{|c|}{ Color } & \multicolumn{3}{|c|}{ Texture properties } & \multicolumn{4}{|c|}{ Sensory properties } \\
\hline & $\mathrm{CI}$ & $\begin{array}{c}\text { External } \\
\text { appearanc } \\
\text { e }\end{array}$ & $\begin{array}{l}\text { Weight } \\
\text { loss }\end{array}$ & TSS & TA & $\mathrm{SL}^{*}$ & $\mathrm{Sa}^{*}$ & $\mathrm{Sb}^{*}$ & $\mathrm{PL}^{*}$ & $\mathrm{~Pa}^{*}$ & $\mathrm{~Pb}^{*}$ & $\begin{array}{l}\text { Hardnes } \\
\mathrm{s}\end{array}$ & $\begin{array}{c}\text { Gummines } \\
\mathrm{s}\end{array}$ & $\begin{array}{c}\text { Chewines } \\
\mathrm{s}\end{array}$ & Color & Flavor & Odor & $\begin{array}{c}\text { Textu } \\
\text { e }\end{array}$ \\
\hline $\mathrm{CI}$ & & & & & & & & & & & & & & & & & & \\
\hline $\begin{array}{c}\text { External } \\
\text { appearance }\end{array}$ & & & & & & & & & & & & & & & & & & \\
\hline Weight loss & & & & & & & & & & & & & & & & & & \\
\hline TSS & $0.58^{*}$ & & & & & & & & & & & & & & & & & \\
\hline TA & & & & $-0.70^{* * *}$ & & & & & & & & & & & & & & \\
\hline $\mathrm{SL}^{*}$ & $0.89 * *$ & & & $0.80^{* * *}$ & & & & & & & & & & & & & & \\
\hline $\mathrm{Sa}^{*}$ & $-0.72 * *$ & $-0.72 * *$ & & & & & & & & & & & & & & & & \\
\hline $\mathrm{Sb}^{*}$ & & & & & $\overline{0.66 *}$ & $0.59 *$ & & & & & & & & & & & & \\
\hline $\mathrm{PL}^{*}$ & & & & & & & & & & & & & & & & & & \\
\hline $\mathrm{Pa}^{*}$ & & & & & & & & & $0.61^{*}$ & & & & & & & & & \\
\hline $\mathrm{Pb}^{*}$ & & & & & & & & & $0.74 *$ & & & & & & & & & \\
\hline Hardness & & & & & & & $-0.70^{*}$ & & & & & & & & & & & \\
\hline Gumminess & & $0.67^{*}$ & & & & & $-0.82 * *$ & & & & & $0.97 *$ * & & & & & & \\
\hline Chewiness & $0.62^{*}$ & $0.68^{*}$ & & & & & $-0.84 * *$ & & & & & $0.92^{* *}$ & $0.98^{* *}$ & & & & & \\
\hline Color & $0.67 *$ & & & & & $0.66^{*}$ & & $\begin{array}{c}0.75^{*} \\
*\end{array}$ & & & & & & & & & & \\
\hline Flavor & & & & & -0.58 * & & & $\begin{array}{c}0.74^{*} \\
*\end{array}$ & & & & & & & $\begin{array}{c}0.66^{*} \\
*\end{array}$ & & & \\
\hline Odor & $0.69^{*}$ & & & $0.78^{* *}$ & & $\begin{array}{c}0.79^{*} \\
*\end{array}$ & & $\begin{array}{c}0.76^{*} \\
*\end{array}$ & & & & & & & 0.90 & $0.66^{*}$ & & \\
\hline Texture & & & & & & & & $0.65^{*}$ & & & & & & & $\begin{array}{c}0.87^{*} \\
*\end{array}$ & $\begin{array}{c}0.72^{*} \\
*\end{array}$ & $\begin{array}{c}0.73^{*} \\
*\end{array}$ & \\
\hline Overall & & & & & & & & $0.61^{*}$ & & & & & & & $\begin{array}{c}0.84^{*} \\
*\end{array}$ & $\begin{array}{c}0.84^{*} \\
*\end{array}$ & $\begin{array}{c}0.77^{*} \\
*\end{array}$ & $0.88^{*}$ \\
\hline
\end{tabular}

CI: Chilling jury; TSS: Total Soluble Solids; TA: Titratable acidity; SL*: Skin of L* values; Sa*: Skin of a* values; Sb*: Skin of $b^{*}$ values; PL*: Pulp of L* values; Pa*: Pulp of a* values; Pb*: Pulp of $b^{*}$ values. P-values below $0.05(*)$ and 0.01 (**) indicate statistically significant non-zero correlations at the $95 \%$ and $99 \%$ confidence level, respectively.

Chilling injury index had a significant positive correlation with TSS, chewiness and sensory properties (Color and odor). Weight loss had no relationship with any parameters. Texture profile parameters had a positive correlation with CI and external appearance, while a negative correlation provided with color of skin.

Table 2 Multiple regression models for CI (Chilling injury), TSS (Total soluble solids), Hardness (texture properties) and overall (sensory properties).

\begin{tabular}{|l|c|}
\hline \multicolumn{1}{|c|}{ Multiple regression model } & $\mathbf{R}^{2}$ \\
\hline CI $=-2.01+0.27($ External appearance $)-3.36 \mathrm{E}-$ & 0.662 \\
$02($ Weight loss $)+8.07 \mathrm{E}-02\left(\mathrm{SL}^{*}\right)-5.05 \mathrm{E}-$ & \\
$02\left(\mathrm{Sa}^{*}\right)-2.17 \mathrm{E}-02\left(\mathrm{Sb}^{*}\right)$ & \\
\hline TSS $=-20.2-0.76($ External appearance $)+$ & 0.675 \\
$0.18($ Weight loss $)+0.43\left(\mathrm{SL}^{*}\right)-2.26 \mathrm{E}-02\left(\mathrm{Sa}^{*}\right)$ & \\
$+0.17\left(\mathrm{Sb}^{*}\right)$ & \\
\hline Hardness $=527.4+1.77\left(\mathrm{External}^{*}\right.$ appearance) $)$ & 0.841 \\
$11.7(\mathrm{Weight}$ loss $)-2.79\left(\mathrm{SL}^{*}\right)-9.97\left(\mathrm{Sa}^{*}\right)-$ & \\
$6.96\left(\mathrm{Sb}^{*}\right)$ & \\
\hline
\end{tabular}

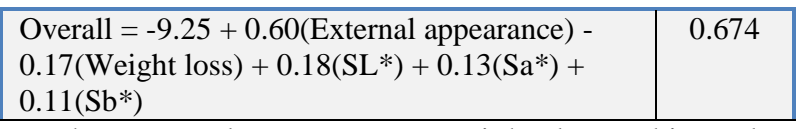

The external appearance, weight loss, skin color revealed a better fit $\left(\mathrm{R}^{2}=0.841\right)$ for hardness (texture properties) of mango. These explanatory variables showed a regression model fit of mango with similar variance explanation of CI, TSS and overall for 0.662 , 0.675 and 0.674 , respectively.

\section{CONCLUSION}

Mango stored at $8{ }^{\circ} \mathrm{C}$ can prolong the shelf-life up to 35 days. Stored mango at $8^{\circ} \mathrm{C}$ can retard physical, physiological and chemical changes. Using only storage temperature at $5{ }^{\circ} \mathrm{C}$ without chitosan coating was sufficient to prolong the storage life of mango. Mangos stored at $8^{\circ} \mathrm{C}$ after curing showed sensory values in color, odor, flavor, texture and overall characteristics significantly better than other treatments. 


\section{ACKNOWLEDGMENTS}

This research was funded by Smile Crops cooperation. The authors are grateful to acknowledge our funding provider.

\section{REFERENCES}

[1] Nunes, M. C. N., Emond, J. P., Brecht, J. K., Dea, S., Proulx, E., Quality curves for mango fruit (cv. Tommy Atkins and Palmer) stored at chilling and nonchilling temperatures, Journal of Food Quality, 2007, 30(1), pp.104-120. DOI:

[2] Akhtar, S., Riaz, M., Ahmad, A., Nisar, A., Physicochemical, microbiological and sensory stability of chemically preserved mango pulp. Pakistan Journal of Botany, 2010, 42(2), pp. 853-862.

[3] Information Technology \& Communication center : Department of Agricultural Extention, Agricultural production information system, 2020. DOI: Agricultural production information system, 2020.pdf

[4] Ministry of Commerce. Thai export market. [Online].Available:http://tradereport.moc.go.th/Re port/Default.aspx?Report=MenucomRecode $\& I m E$ xType $=1 \&$ Lang=Th. $(2021$, September $)$

[5] W.G. Cárdenas-Coronel, R. Velez-de la Rocha, J.H. Siller-Cepeda, T. Osuna-Enciso, M.D. Muy-Rangel, J.A. Sañudo-Barajas, Changes in the composition of starch, pectin and hemicelluloses during the ripening stage of mango (Mangifera indica). Rev. Chapingo Serie Hortic, 2012, 18, pp. 5-19.
[6] Maldonado-Celis, M. E., Yahia, E. M., Bedoya, R., Landázuri, P., Loango, N., Aguillón, Guerrero Ospina, J. C., Chemical composition of mango (Mangifera indica L.) fruit: Nutritional and phytochemical compounds. Frontiers in plant science, 2019, 10, pp. 1073.

[7] Romanazzi, G., Feliziani, E., Baños, S. B., Sivakumar, D., Shelf life extension of fresh fruit and vegetables by chitosan treatment. Critical reviews in food science and nutrition, 2017, 57(3), pp. 579601.

[8] Adiletta, G., Pasquariello, M. S., Zampella, L., Mastrobuoni, F., Scortichini, M., Petriccione, M., Chitosan coating: A postharvest treatment to delay oxidative stress in loquat fruits during cold storage. Agronomy, 2018, 8(4), pp. 54.

[9] Wang, C. Y., Wang, S. Y., Effect of storage temperatures on fruit quality of various cranberry cultivars. Acta Horticulturae, 2009, 810, pp. 853862.

[10] Hussen, A., Impact of temperature and relative humidity in quality and shelf life of mango fruit. Int. j. hortic. food sci., 2021, 3(1), pp. 46-50.

[11] Arampath PC, Dekker M., Bulk storage of mango (Mangifera indica L.) and pineapple (Ananas comosus L.) pulp: effect of pulping and storage temperature on phytochemicals and antioxidant activity. Journal of the Science of Food and Agriculture, 2019, 99(11), pp. 5157-5167. 